Review

\title{
A Closer Look at Schlemm's Canal Cell Physiology: Implications for Biomimetics
}

\section{Cula N. Dautriche, Yangzi Tian, Yubing Xie and Susan T. Sharfstein *}

State University of New York (SUNY) Polytechnic Institute, Colleges of Nanoscale Science and Engineering, 257 Fuller Road, Albany, NY 12203, USA;

E-Mails: cula.dautriche@downstate.edu (C.N.D.); yitian@sunypoly.edu (Y.T.); yxie@sunypoly.edu (Y.X.)

* Author to whom correspondence should be addressed; E-Mail: ssharfstein@sunypoly.edu; Tel.: +1-518-437-8820; Fax: +1-518-437-8687.

Academic Editor: Dimitrios Karamichos

Received: 30 June 2015 / Accepted: 6 September 2015 / Published: 21 September 2015

\begin{abstract}
Among ocular pathologies, glaucoma is the second leading cause of progressive vision loss, expected to affect 80 million people worldwide by 2020. A primary cause of glaucoma appears to be damage to the conventional outflow tract. Conventional outflow tissues, a composite of the trabecular meshwork and the Schlemm's canal, regulate and maintain homeostatic responses to intraocular pressure. In glaucoma, filtration of aqueous humor into the Schlemm's canal is hindered, leading to an increase in intraocular pressure and subsequent damage to the optic nerve, with progressive vision loss. The Schlemm's canal encompasses a unique endothelium. Recent advances in culturing and manipulating Schlemm's canal cells have elucidated several aspects of their physiology, including ultrastructure, cell-specific marker expression, and biomechanical properties. This review highlights these advances and discusses implications for engineering a $3 \mathrm{D}$, biomimetic, in vitro model of the Schlemm's canal endothelium to further advance glaucoma research, including drug testing and gene therapy screening.
\end{abstract}

Keywords: Schlemm's canal; conventional outflow tract; intraocular pressure; glaucoma; biomimetics; tissue engineering; nanofabrication 


\section{Introduction}

The Schlemm's canal (SC), named after the German anatomist, Friedrich Schlemm and first identified in 1830 [1], is a unique, ring-shaped, endothelium-lined vessel that encircles the cornea [2,3] (Figure 1). Anatomically, it is situated directly against the juxtacanalicular (JCT) region of the trabecular meshwork (TM). As a consequence, one of its primary functions is to deliver aqueous humor into the collecting channels, following filtration through the TM. Because of its close apposition to the JCT, not all SC cells are created equal. As a result, the SC is divided into the inner and outer wall, each possessing endothelial cells that differ in morphology [4], cell-specific marker expression [5,6], specialized cellular organelles, and functions (Table 1). However, these differences may be due to the differences in biomechanical environment between the inner and outer wall, rather than any underlying biological or biochemical differences between the inner and outer wall endothelia. The inner wall has been more extensively studied, as the greatest resistance to aqueous humor outflow is generated in or close to the SC endothelium that lines the TM [7-11]. Excessive resistance leads to elevated intraocular pressure (IOP), the leading modifiable risk factor for glaucoma. This review will focus on the development, anatomy, biology and physiology of SC inner wall endothelial cells as they are relevant to engineering the SC inner wall.

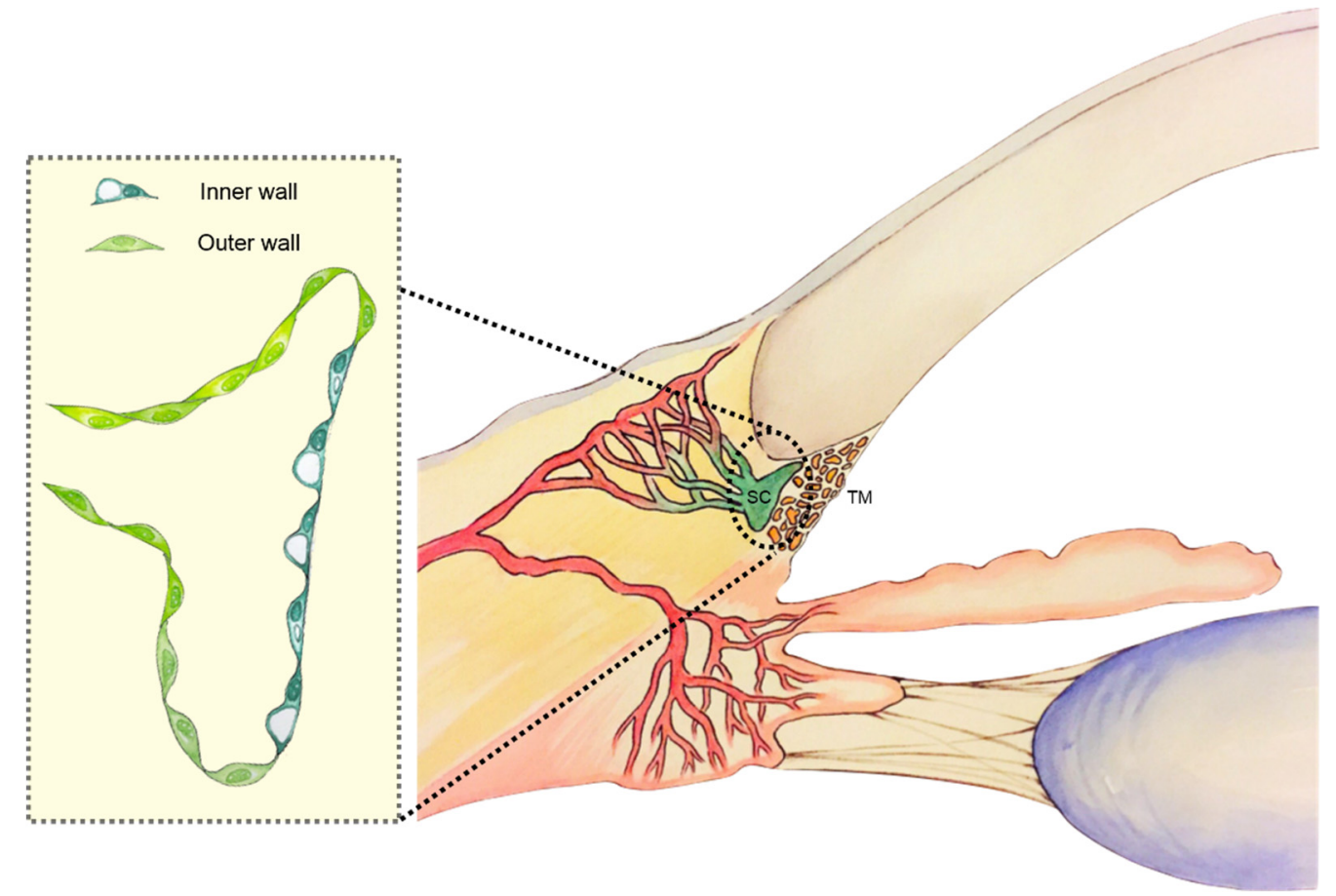

Figure 1. Schematic of the conventional outflow pathway. The left inset shows an expanded view of the Schlemm's canal's microanatomy detailing the cell morphology of the inner and outer wall.

The inner wall of the SC is a unique endothelium, specialized to maintain aqueous humor homeostasis, and IOP regulation in conjunction with the TM. Unlike the TM, controversy remains regarding the SC, especially in terms of development, its contribution to outflow resistance in normal and glaucomatous states, and its role in ocular immunity. This is, in part, due to the very limited amount of SC tissue 
available as well as the difficulty in isolating SC cells. Moreover, 2D culture of SC cells on tissue culture plastic results in dedifferentiation of the SC cells [12], limiting its utility as a clinical model. Advances in nanotechnology, particularly materials science, have permitted cultures of SC cells in more biomimetic environments, leading to significant advances in characterizing SC cell mechano-biology and physiology, which highlights the extremely dynamic nature of the inner wall $[13,14]$.

Table 1. Characteristics of Schlemm's canal endothelial cells.

\begin{tabular}{ccc}
\hline Property & Inner Wall & Outer Wall \\
\hline Morphology & $\begin{array}{c}\text { Cobblestone appearance [15] } \\
\text { Discontinuous basement membrane [15,16] }\end{array}$ & $\begin{array}{c}\text { Smooth and flat [5], } \\
\text { continuous basement membrane [17] }\end{array}$ \\
\hline $\begin{array}{c}\text { Cell-specific } \\
\text { marker }\end{array}$ & Zipper-like VE-cadherin [18] & $\begin{array}{c}\text { Desmin } \\
\text { Reactivity to Factor VIII-related antigen [19] }\end{array}$ \\
\hline $\begin{array}{c}\text { Subcellular } \\
\text { structure }\end{array}$ & Giant vacuoles [20], paracellular pores [21] & Weibel-Palade bodies [17] \\
\hline Function & $\begin{array}{c}\text { Aqueous humor filtration } \\
\text { IOP homeostasis [5,22,23] }\end{array}$ & Unknown \\
\hline
\end{tabular}

\section{Embryological Origin: Of Lymph or Blood?}

One of the greatest controversies that surrounds the unique endothelial nature of the $\mathrm{SC}$ is its embryological origin. Although earlier studies suggested a vascular origin [17,24-26], recent publications establish the SC as a lymphatic-like vessel. In humans, prenatal SC development begins at week 17 [5] and is completed by week 24 [27], whereas in mice, the SC development is postnatal [2]. The organogenesis of the SC is a stepwise process in which SC progenitors are first specified in the transscleral veins and bud off laterally to anastomose, with subsequent lumenization and development into the mature SC (Figure 2) [28-30]. Park and Aspelund and their respective coworkers elucidated key molecular mechanisms and characteristics of SC progenitors for their terminal differentiation into SC cells, while contrasting it with lymphatic cell development (Figure 2). Although in mice, SC development is postnatal, unlike the embryonic development of the lymphatic system, both processes involve migration of venous endothelial cell (VEC) progenitors that undergo precise, orchestrated changes in key markers for subsequent acquisition of lymphatic identity (Table 2) [28,31].

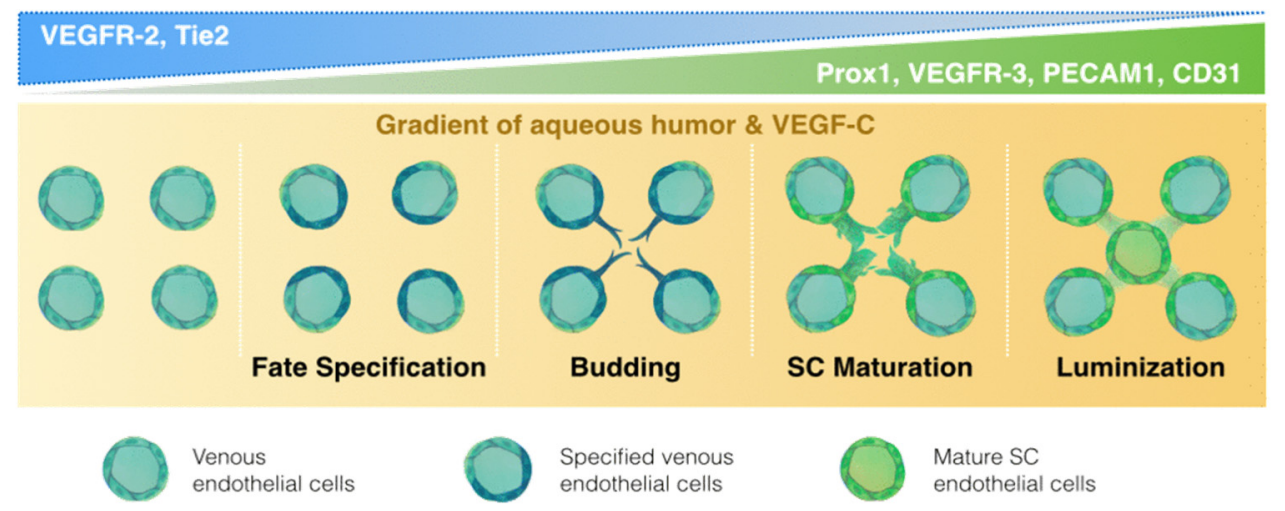

Figure 2. Organogenesis of the Schlemm's canal with a focus on key differential expression pattern along with essential soluble factors. 
Table 2. Summary of key signaling necessary for Schlemm's canal or lymphatic development in mice.

\begin{tabular}{|c|c|c|c|c|c|}
\hline Lineage & Development & Progenitors & Budding & $\begin{array}{l}\text { Lumenization/ } \\
\text { Sac Formation }\end{array}$ & $\begin{array}{c}\text { Separation from } \\
\text { Venous Vasculature }\end{array}$ \\
\hline Lymphatic & Embryonic & $\begin{array}{c}\text { PROX1 [32], } \\
\text { Sox18 [33], } \\
\text { COUP-FII [34], } \\
\text { VE-cadherin [35] }\end{array}$ & $\begin{array}{c}\text { PDPN [36], } \\
\text { VEFGR3 [37], } \\
\text { CCBE1 [38], } \\
\text { NRP2 [39], } \\
\text { RAC1 [40], } \\
\text { LYVE-1 [41] }\end{array}$ & $\begin{array}{c}\text { NFATC1 }[42], \\
\text { GATA2 }[43,44], \\
\text { Calcr1 }[45], \\
\text { Ramp2 [45], } \\
\text { TIE1 [46] }\end{array}$ & $\begin{array}{c}\text { Syk [47], SLP76 [47], } \\
\text { Runx1 [48], } \\
\text { PDPN [36], } \\
\text { Meis1 [49], } \\
\text { Clec2 [50,51], } \\
\text { CXADR [52] }\end{array}$ \\
\hline $\begin{array}{l}\text { Schlemm's } \\
\text { Canal }\end{array}$ & Postnatal & $\begin{array}{l}\text { VEGFR-2, } \\
\text { TIE } 2[2,28]\end{array}$ & PROX1 [2,28,55] & VEFGR-3 $[2,28]$ & $\begin{array}{c}\text { PECAM1, } \\
\text { VEFGR-3 }[2,18,28]\end{array}$ \\
\hline
\end{tabular}

The SC development may be classified into four stages, SC progenitor cell-fate specification, lateral sprouting, lumenization, and separation from venous vasculature. Unlike lymphatic progenitor cell-fate specification, the key regulatory molecules and specific markers needed to mediate SC progenitor cell-fate specification have not been clearly identified. Aspelund et al. demonstrated that vascular endothelial growth factor (VEGF)-C is necessary to initiate migration of VECs and lateral sprouting from the transscleral veins. Park and Aspelund and their respective coworkers elegantly demonstrated that SC progenitor cells are VECs that are positive for vascular endothelial growth factor receptor (VEGFR) 2 and the tunica interna endothelial cell kinase (TIE) 2. These SC progenitor cells subsequently acquired PROX1 expression for lumenization and VEGFR-3 for subsequent maturation into SC cells [2,28] (Figure 2). Truong et al. were the first to demonstrate high expression of the lymphatic transcription factor, PROX1, in SC endothelium, suggesting a closer similarity between SC endothelium and lymphatic endothelium [54]. Both aqueous humor and VEGF-C are required for proper SC development. VEGF-C (VEGFc+/LacZ) heterozygous mice exhibited delayed budding of SC endothelial cells from the venous system and retarded tubular fusion [2,28]. Meanwhile, reduction of aqueous humor resulted in endothelial-mesenchymal transition and loss of the lymphatic identity [28]. Thus, the SC in mice is a unique, specialized endothelium of vascular origin that undergoes partial lymphatic reprogramming during postnatal development to acquire a transient lymphatic identity required for maintaining its proper function in aqueous humor homeostasis [2,28,55]. Similar to lymphatic cells, SC cells experience flow from a basal to apical direction. While these studies were conducted in mice, expression of PROX1 by SC endothelial cells in humans, zebrafish, and mice indicates that the lymphatic-like identity of the SC is conserved in vertebrate evolution [2], and suggests that similar developmental pathways are likely to occur in humans, albeit prenatally rather than postnatally.

Despite their lymphatic nature and expression of several (though not all) lymphatic markers, SC cells do not appear to have lymphatic origins. Kizhatil et al. recently detailed the organogenesis of the SC, which arises from the limbal vascular plexis (LVP) and radial vessels (RV) deep in the limbus that run in a direction perpendicular to the LVP. They coined the term canalogenesis to describe this process [53]. Canalogensis, the authors argued, is very similar to vascular development, emphasizing a more vascular origin or identity of the SC cells. However, there are important differences between angiogenesis and canalogenesis. In canalogenesis, following endothelial sprouting and tip cell formation, tip cells migrate into an intermediate zone between the LVP and RV to interact and adhere to each other, forming clusters 
of tip cells. The cells in these clusters divide, producing a chain of cells which acquire PROX1 expression for formation and remodeling into a tube, which is the SC. They further demonstrated that specification of the inner and outer wall of the SC is established during development with differential expression of key markers such FLT4 and PROX1.

Understanding the exact molecular footprint of SC organogenesis is at its infancy. However, these studies have radically advanced our knowledge of organogenesis of the SC. Still, important questions remain to be investigated to understand the critical contribution of the SC to aqueous humor homeostasis and glaucoma pathogenesis. For example, what determines the number of SC progenitors that will bud from the transscleral veins? What is the exact molecular footprint of SC progenitors? What triggers aqueous humor influx into the SC? What is the role of aqueous humor in the acquisition of the SC phenotype? What additional key regulators and signaling pathways are likely to participate in SC progenitor differentiation and maturation? What are the molecular events that facilitate separation from the venous system? What factors specify the cell fate of endothelial cells in the inner wall and the outer wall of the SC? Answers to these questions will facilitate establishment of platforms for manipulating SC progenitor cells to address the scarcity of SC cells available for research as well as further our understanding of human Schlemm's canal inner wall (HSCIW) cell biology and physiology.

\section{Schlemm's Canal Anatomy}

\subsection{Macroarchitecture}

The SC is located at the drainage or iridocorneal angle. The iridocorneal angle is lined by the TM, which overlies the SC. Together, they make up the conventional outflow tract and account for $50 \%-90 \%$ of aqueous humor outflow [22,54,56-58]. The SC is an endothelium-lined circular canal with branching of several aqueous channels. Until recently, the anatomy of the SC was characterized by histological stains, which estimated the SC cross-sectional area to be $1709 \mu^{2}$ [58]. Recent, live, 3D, non-invasive visualization has facilitated more detailed and physiological measurement of the SC. As a result, the cross-sectional area is now estimated to vary between 4064 to $7164 \mu \mathrm{m}^{2}$ [59-63], with many branched aqueous channels [64,65] (Figure 1).

\subsection{Microarchitecture}

The macroarchitecture of the SC dictates its microanatomy. The SC is lined by a continuous endothelium with tight junctions, which is divided into an outer and inner wall with regards to its relationship to the JCT (Figure 1). The SC endothelium that lies directly against the JCT is known as the inner wall and is the most celebrated and studied. The remaining endothelia comprise the outer wall. The endothelial cells of the inner wall differ from that of the outer wall in morphology, cell-specific markers and functions. In contrast to the outer wall, inner wall endothelial cells lie on a discontinuous basement membrane $[15,66]$ and are specialized to handle flow in a basal-to-apical direction like lymphatic endothelium. The endothelial cells of the outer wall are differentiated from the inner wall endothelia by the presence of Weibel-Palade bodies [17], a positive desmin stain [67], and strong reactivity to Factor VIII-related antigen [17]. Because of their location against the JCT, the inner wall endothelial cells experience a unique biomechanical microenvironment that subjects them to a basal-apical pressure 
gradient. As a consequence, endothelial cells of the inner wall exhibit pores and giant vacuoles, as well as F-actin arrangements that are distinct from that of the outer wall [68]. Outer wall endothelial cells have stellate actin arrangements throughout much of the cell as compared to prominent peripheral F-actin bands observed in inner wall endothelial cells [68]. Giant vacuoles are not intracellular structures, but rather deformations of the inner wall to create a small potential space between the extracellular matrix (ECM) of the JCT and the inner wall [5]; whereas pores are inner wall structures with sizes between 0.6 and $3 \mu \mathrm{m}[13]$ that mediate aqueous transport into the SC and may account for the SC contribution to aqueous outflow [21,69-72].

Two types of pores have been identified and characterized, I-pores (transcellular) and B-pores (paracellular) [21,73], which differ in location, sensitivity to strain and mechanisms of formation [13]. While B-pores result from local disassembly and widening of intercellular junctions, I-pores may be a result of fusion of the apical and basal cell membranes that may come into apposition as the cytoplasm thins under applied strain, with caveolae, vesicles, or "mini-pores" [13,74,75]. In addition, Braakman et al. recently illustrated aqueous outflow segmentation mediated by these pores, mainly B-pores [23]. Glaucomatous eyes exhibit decreased density of these pores, highlighting the vital role of the inner wall in aqueous humor homeostasis. Therefore, a goal of SC-targeted therapies might be to increase pore density and hence outflow, thus lowering IOP in glaucoma.

\section{Characteristics of Human Schlemm's Canal Cells}

The cobblestone appearance of the HSCIW cells is attributed to the significant biomechanical load experienced as well as the segmental flow of aqueous humor [5,76]. Segmental flow relates to the non-homogenous filtration of aqueous humor in the JCT, with greater flow occurring through certain portions of the TM and less through other portions, which has been attributed to the presence or absence of pores within the HSCIW $[23,77,78]$. The degree of biomechanical stress directly affects the morphology of the inner wall, as its endothelial cells are described as elongated and aligned to the longitudinal axis of the SC, with some flattened and some with dome-like outpouchings (giant vacuoles) [13,57]. Because of their unique development, SC cells share morphological characteristics and cell marker expression with both lymphatic and venous endothelial cells (Table 3). In conventional 2D culture, SC cells are characterized as a homogeneous and elongated monolayer. The characteristic monolayer exhibits a net transendothelial electrical resistance of $10 \Omega \cdot \mathrm{cm}^{2}$ or greater [79], an absence of myocilin induction by dexamethasone, and expression of vascular endothelial cadherin (VE-cadherin), integrin $\alpha 6$, and fibulin-2 [79,80]. In vivo, SC cells are positive for PROX1 (with much higher levels for HSCIW cells than outer wall cells), integrin $\alpha 9$, and CD31, but negative for the differentiated lymphatic markers LYVE-1 and podoplanin, as well as the blood vessel marker SMA $[2,28,55,79,80]$. The cytoskeleton of $\mathrm{SC}$ cells is enriched in both microfilaments and intermediate filaments, and has a prominent actin-enriched cell cortex [81]. Although traditional 2D culture systems allow for manipulation of the SC endothelial cells, SC cells in traditional culture systems usually lose essential signaling, both mechanical and biochemical, required for proper maintenance of their in vivo phenotypes [5,79], reducing the utility of information obtained from such systems. Therefore, 3D culture systems may promote in vivo-like SC morphology, marker expression and function. 
Table 3. Comparison of Schlemm's canal, lymphatic, and vascular endothelial properties.

\begin{tabular}{cccc}
\hline $\begin{array}{c}\text { Molecular/Cellular } \\
\text { Characteristics }\end{array}$ & $\begin{array}{c}\text { Schlemm's Canal } \\
\text { Endothelium }\end{array}$ & $\begin{array}{c}\text { Lymphatic } \\
\text { Endothelium }\end{array}$ & $\begin{array}{c}\text { Vascular } \\
\text { Endothelium }\end{array}$ \\
\hline Sox18 & - & $+[33]$ & - \\
VEGFR-2 & $+[2,28]$ & - & $+[82]$ \\
VEGFR-3 & $+[2,28]$ & $+[38]$ & $+[83]$ \\
PROX1 & $+[2,28,53]$ & $+[34]$ & - \\
CCL21 & $+[2,28]$ & - & - \\
Itga9 & $+[2]$ & - & - \\
Collagen IV & $+[2]$ & - & - \\
PECAM1 & $+[18]$ & - & $+[84]$ \\
VE-cadherin & $+[18]$ & $+[35]$ & $+[85]$ \\
Endomucin & $+[53]$ & - & - \\
Foxc2 & $+[2,28]$ & - & - \\
LYVE-1 & - & $+[41]$ & - \\
Podoplanin & - & $+[36]$ & - \\
vWF & $+[17]$ & - & $+[86]$ \\
Wiebel-Palade bodies & $+[17]$ & - & $+[86]$ \\
Endothelial monolayer & continuous [5] & continuous [29,87] & continuous \\
Basement membrane & discontinuous [5] & discontinuous [29,87] & continuous \\
Basal-to-apical Flow & $+[5,88]$ & $+[87,89]$ & - \\
\hline
\end{tabular}

${ }^{a}$ Note that these studies did not distinguish between inner and outer wall endothelia.

We recently highlighted the importance of providing the proper 3D spatial and biochemical cues in engineering a 3D SC in vitro model [90]. We demonstrated that 3D culture of HSC cells on microfabricated scaffolds with well-defined physical and biochemical cues, rescued expression of key HSC markers, such as VE-cadherin and PECAM1, and mediated pore formation, crucial for the SC regulation of IOP. Whether the in vivo SC has been functionally or structurally replicated or even completely simulated remains to be determined with studies of physiological and structural responses to drugs and modulation of genes expression for genes such as VEGF-C.

\section{Biomechanics}

As a result of its location against the JCT, the HSCIW experiences a biomechanical microenvironment that is much closer to that of lymphatic endothelia than that of vascular endothelia. Similar to lymphatic endothelium, the HSCIW endothelia experience a basal to apical pressure gradient during aqueous outflow. Unlike lymphatic endothelium, the HSCIW endothelium is sealed by tight junctions, and thus, must support the basal-to-apical pressure drop between IOP and episcleral venous pressure, which tends to deform HSCIW cells off their supporting basement membrane, creating giant vacuoles [89,91-94]. As a result, HSCIW cells are highly contractile [95] with an estimated elastic modulus of 1-3 kPa, similar to, but somewhat larger than other endothelial cells $[88,96]$. In addition, as a consequence of the basal-to-apical flow, HSCIW cells also exhibit transcellular and paracellular pores to mediate aqueous humor transport [21,97-99]. Their unique location against the JCT subjects HSCIW endothelial cells to biomechanical signals from the JCT's ECM [100], causing modification of gene expression to accommodate 
changes in substrate stiffness. HSCIW cells stiffen in response to increasing substrate stiffness, with glaucomatous HSCIW cells being more sensitive to substrate stiffness and having a larger stiffening response [88]. HSCIW cells' ability to adapt to large deformations and respond to their microenvironment is reflected in a cytoskeletal arrangement enriched in actin microfilaments and intermediate filaments [81]. Clearly, the HSCIW's biomechanical microenvironment plays an important role in maintaining HSCIW cells phenotype and proper function.

\section{Perspective on Schlemm's Canal Engineering}

Although conventional 2D tissue culture is currently the primary system for evaluating and characterizing HSC cell properties, its limitations have severely impeded our understanding of trabecular outflow physiology as well as glaucoma pathology and drug screening. Currently, there is no glaucoma therapy that lowers IOP via mechanisms that target the physiology of HSCIW endothelial cells. This is, in part, due to our poor understanding of the pathology at the SC, particularly the HSCIW during glaucoma development as well as the lack of an in vitro system for 3D culture of these cells under flow conditions, which is necessary to capture their in vivo characteristics and obtain relevant clinical information. The remainder of this review will highlight the main challenges and opportunities in establishing cellular microenvironments for engineering 3D HSCIW constructs, including sources of HSCIW cells, biomaterials to mimic ECM, and soluble factors to direct and maintain functional HSCIW differentiation.

\subsection{Criteria for a 3D in Vitro Model of the Schlemm's Canal Inner Wall}

Until recently, HSC cell culture has been limited to traditional 2D culture or culture on microporous Transwell ${ }^{\circledR}$ inserts. These studies have resulted in a tremendous amount of information on cell biology, physiology, and biomechanics. More importantly, these studies have highlighted the limitations of current systems as well as the critical attributes that a $3 \mathrm{D}$ in vitro system should recreate to correlate well with the in vivo characteristics and physiologic cellular response. From these studies, it is clear that any in vitro 3D model of the HSCIW should perform the following functions:

(1) Express key cell-specific markers, necessary for the endothelial integrity and mechanosensing;

(2) Display both paracellular and transcellular pathways vital to aqueous outflow function of the SC;

(3) Mimic the in vivo cellular micro architecture with respect to morphological features such as a cellular dimensions or surface area of cell-cell interactions within the cultured monolayer, the spatial distribution of subcellular organelles (vacuoles), the complexity of tight junctional strands;

(4) Allow for ease of culture using phenotypically stable cell lines to facilitate high throughput screening. Thus, a well-characterized in vitro 3D model of the HSCIW would provide a system in which to study and understand the physiology, biomechanics, outflow functions, physiological drug responses as well as pathological processes in glaucoma.

\subsection{Potential Sources of Human Schlemm's Canal Inner Wall Endothelial Cells}

One of the biggest challenges facing SC inner wall engineering is the scarcity of these cells [101]. Selective isolation of HSC cells from the limited amount of corneoscleral remnants remains an art. 
To date, very few laboratories $[6,79,102,103]$ have developed complex protocols for successful isolation and culture of these cells and have become the primary supply sources for HSC cells, which will certainly contain both inner and outer wall HSC cells. In addition, successful isolation of these cells depends on a variety of uncontrollable factors, such as the age of the donor, duration of storage of the tissue after surgical removal before cell isolation, etc. These challenges have dramatically hindered the availability of SC cells for research and speak to the need to identify new ways of obtaining these cells. Stem cell differentiation [104-106] is an attractive avenue to explore as an alternative way of obtaining HSC cells with possible selection for HSCIW cells. Although stem cell differentiation to generate TM cells has been successfully documented [107-110], there are no reports addressing SC differentiation from stem cells. Recent publications $[2,28,55]$ on the organogenesis of the SC have highlighted key factors and signaling molecules (e.g., PROX1 [32], VEGFR-3) that are necessary for acquisition of the SC phenotype from transscleral veins. These recent studies suggest the possibility of using primordial endothelial cells and/or venous endothelial cells [111-114] as a strategy to obtain HSCIW cells through directed differentiation (Figure 3).

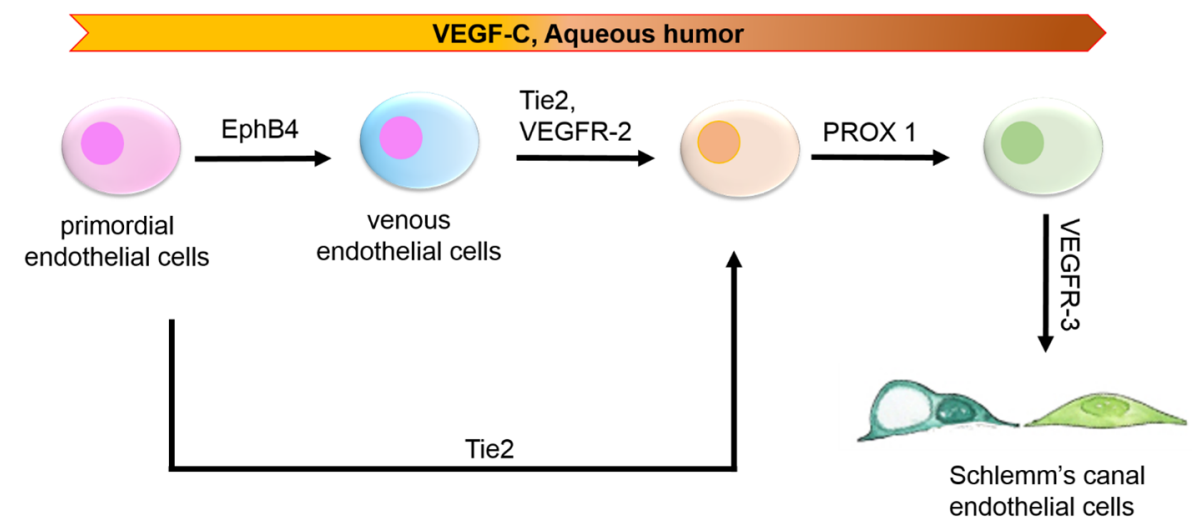

Figure 3. Potential strategies for stem cell differentiation into Schlemm's canal endothelial cells.

\subsection{Biomaterials for 3D Culture of Human Schlemm's Canal Inner Wall Cells}

In addition to the scarcity of HSC cells, challenges in conventional 2D culture of HSC cells have impeded our understanding of the functional contribution of the SC to outflow physiology and glaucoma pathology. HSC cells in conventional 2D culture are distinct from their in vivo counterpart as they lose expression of key in vivo cell-specific markers $[18,79,80]$. This dedifferentiation speaks to the need to engineer an in vitro model of the SC that can mimic the in vivo microenvironment, eventually capturing the $3 \mathrm{D}$ in vivo characteristics of these cells. Given that the SC inner wall layer is only a few microns thick [96,115], a top-down approach to engineering the inner wall may be the most feasible strategy. In the traditional top-down approach, exogenous biocompatible and mechanically competent scaffolds are fabricated for 3D culture of the cells, which are then allowed to populate the scaffold, deposit and remodel their ECM.

Scaffolds are fundamental to tissue engineering. Their functions include providing mechanical support, supporting ECM production and cell colonization, and waste-nutrient exchange [116-118]. As a consequence of its endothelial origin, scaffold materials and fabrication techniques being used in vascular tissue engineering can provide insight into engineering the SC [119-122] although different 
geometries will be required due to the unique nature of the SC canal, in particular, the polarization between in the inner and outer wall. Successful biomaterials for scaffolding for SC engineering might incorporate synthetic polymers, for their mechanical strength and well controlled porosity [123], and natural polymers, for their biochemical cues. In our previous work, we adapted the negative photoresist, SU-8, to provide the necessary topographical and mechanical cues while using the hydrogel Extracel ${ }^{\mathrm{TM}}$ to promote cell attachment and maintenance of SC cells differentiated functions [90].

Micro and nanofabrication techniques, such as lithography and electrospinning, are versatile fabrication techniques widely used in production of fibrous and porous scaffolds for vascular tissue engineering. Given the porous nature of the conventional outflow tract, scaffold considerations for SC engineering should be tailored to mimicking the pore structures (e.g., pore size, porosity), and in particular, extracellular, biochemical, and biomechanical microenvironments of the region directly against the SC, the JCT. Pore sizes and ECM fiber diameters in the JCT range from 2 to $15 \mu \mathrm{m}$ [16]. Thus, scaffolds with various permutations of these properties might facilitate 3D culture of SC cells. In addition, biochemical cues play a paramount role in maintaining cell phenotype and function. The JCT ECM components, by virtue of their location against the HSCIW, might be providing key biochemical signaling for HSCIW cell growth and function. Thus, natural polymers of ECM components $[8,124]$ like those found in the JCT, such as hyaluronic acid and collagen IV can be used to provide biochemical cues for HSCIW cell growth and function. Therefore, microfabricated scaffolds of synthetic polymers can be surface-coated or chemically modified with ECM components found at the JCT-SC border to provide key biochemical cues for successful HSCIW engineering. ECM components, such as hyaluronic acid [125-127] and collagens [128-130], have been used to support endothelial cell proliferation and function, indicating their potential to modify microfabricated scaffolds for HSCIW engineering. Additionally, the stratification of these ECM components at the JCT-SC interface highlights their potential as scaffolding materials or scaffold supplements for 3D HSCIW cell culture.

\subsection{Soluble Factors for Directed Schlemm's Canal Cell Differentiation}

Cellular differentiation is a result of coordinated dynamic expression of hundreds of genes and proteins in precise response to external signaling cues [106,131], which include soluble factors and spatio-physical cues from the ECM. Soluble factors mediate cellular differentiation by binding to cell surface receptors, thus activating downstream signaling [132]. Lineage specification of soluble factors, of the same stem cell type, differs depending on whether the stem cells were cultured in $3 \mathrm{D}$ or $2 \mathrm{D}$ configurations. For example, when induced to differentiate in restrictive ECM environments, adhesive, flattened human mesenchymal stem cells (hMSCs) in 2D preferentially adopt an osteogenic phenotype, whereas round hMSCs in 3D cultures preferentially undergo adipogenesis [133-135]. Thus, soluble factors and spatio-temporal cues in 3D culture are vital in providing the microenvironment necessary for differentiation, and may favor one lineage over another.

Park and Aspelund and their respective coworkers have elegantly elucidated key molecular footprints of venous endothelial cell differentiation to SC cells. Together, their data highlights the essential role of soluble factors such as VEGF-C, VEGF-D and aqueous humor for venous endothelial cells to acquire SC cell identity and for proper development of the SC. In addition, these data suggest the possibility of using these factors to mediate differentiation of induced pluripotent stem cells into SC cells [136]. Given 
the intimate relationship of the HSCIW to the JCT and that TM development precedes SC development, it is equally likely that soluble factors from the JCT cells may be vital to acquiring and maintaining the SC/HSCIW phenotype. Several groups have documented that cytokine (TNF- $\alpha$, IL1- $\alpha$, IL- $\beta$, and IL-8) release by TM cells mediates SC cell function in regulating aqueous humor outflow $[100,137,138]$, highlighting the possible role of TM cells and their soluble factors in SC differentiation. Nitric oxide (NO) has been extensively studied for its role in modulating SC cell behavior to regulate aqueous outflow $[3,103,139]$. Because of the important role that NO plays in facilitating SC cell functions and endothelial junctional integrity, this warrants exploring the role of NO in SC development [140]. Furthermore, given the vascular origin of the SC and its lymphatic-like development and characteristics, it is important to consider soluble factors involved in vascular endothelial and lymphatic cell differentiation. Because of the unique biomechanical environment of the SC, direct addition of soluble factors to a 3D culture of the HSCIW cells may not be sufficient. Hence, controlled and sustained delivery of these soluble factors may be crucial for successful differentiation. Thus, other approaches such as nanoparticle-based delivery or conjugation to nanofibers that facilitate timed and spatial release should be consider for the delivery of soluble factors to induce SC cell differentiation and organogenesis [141-145].

\subsection{Dynamic 3D Culture}

The in vivo forces generated by aqueous humor flow play an important role in the SC organogenesis $[2,28]$. They are vital in maintaining the morphology and physiology of the HSCIW cells. Several groups have attempted to replicate the dynamic microenvironment of HSCIW cells in vitro through culture on microporous Transwell ${ }^{\circledR}$ membranes [100,146-148]. Together these studies have highlighted possible mechanisms for aqueous humor transport across the HSCIW, namely via formation of giant vacuoles and paracellular pores. They have further demonstrated the important role of the pressure gradient in modulating the barrier function of the HSCIW through regulation of junctional proteins. While these studies were able to capture the in vivo cell polarization and provided tremendous information regarding the biomechanics of the HSCIW, this system is not ideal to study aqueous outflow, or to perform continuous perfusion, medium exchange or gradient studies, particularly in response to key signaling factors like VEGF-C. These limitations are due to the nature of Transwell ${ }^{\circledR}$ membranes, which are track-etched and possess irregular pore structures or have low porosity (i.e., 4\%-20\%), indicating poor topographical approximation [149] and limiting their performance for assessing physiologic parameters [150]. In addition, culture of endothelial cells on Transwell ${ }^{\circledR}$ membranes results in a less stringent endothelial barrier with the occurrence of irregular patterns of cell adhesion or "edge effect" [151], hampering the integrity of the endothelial monolayer. Thus, culture of HSCIW cells on Transwell ${ }^{\circledR}$ membranes to assess physiologic parameters uniquely associated with these cells may limit the clinical relevance obtained from such systems. Therefore, culture methods which incorporate a dynamic flow element might be instrumental not only for HSCIW cell differentiation, but for proper simulation and maintenance of the HSCIW phenotype in vitro. Dynamic flow system such as direct perfusion bioreactors and microfluidic devices that enable sophisticated control of the spatial, temporal profile of gradients as well as flow velocities are more suitable to culture of SC cells.

The in vitro system we previously described overcame some of the limitations of commercially available Transwell ${ }^{\circledR}$ membranes. Using photolithography techniques, we fabricated highly porous 
SU-8 membranes with pre-defined porosity, well-controlled, uniform pore size, shape, and beam width [90,152,153], demonstrating that well-defined SU-8 scaffolds support a more in vivo-like SC morphology, characterized by re-expression of key in vivo endothelial markers, PECAM1 and VE-cadherin, pore formation and outflow function. This system is a major step forward in the culture of $\mathrm{SC}$ cells, but it does not simulate the in vivo structure, in terms of fluidic or mechanical stress [90]. More studies are needed exploring 3D cultured cells in systems that can better simulate their in vivo dynamic microenvironment [154]. For instance, several studies have documented the importance of mimicking the dynamic microenvironment in lymphatic endothelial cell culture, demonstrating the critical role of interstitial flow in modulating lymphatic endothelial cell proliferation, migration and function $[155,156]$. In the case of cardiac cell differentiation, culture methods that incorporate a dynamic flow element improve cardiogenesis, beating percentage in size-controlled hESC-derived embryoid bodies (EBs), and cardiac gene expression at mRNA and protein levels in mESC-derived EBs [157-160] when compared to traditional static culture methods [161]. Therefore, in a similar fashion, replicating the dynamic microenvironment via continuous perfusion through SC cells might result in differences in cellular morphology, junctional complex expression and formation, and even outflow regulation. In addition, commercial Transwell ${ }^{\circledR}$ membranes are not ideal for co-culture, as they are too thick to allow for necessary cell-cell communications and their low porosity for appropriate rate of nutrients and paracrine signal exchange. Given that the HSCIW is in close apposition to the JCT, the most optimal culture system for both the SC cells and trabecular meshwork cells, is a co-culture on a membrane thin enough to allow for direct cell-cell communication, paracrine signals and a membrane strong enough to withstand appropriate flow velocities while under continuous perfusion. Thus, the fluid dynamics of the SC must be captured in vitro, for proper simulation of the in vivo tissue to obtain more clinically relevant responses, especially for drug studies.

\section{Conclusions}

The SC is a unique vascular endothelium with lymphatic-like characteristics that functions to mediate IOP outflow homeostasis together with the TM. The exact contribution of the SC is yet to be delineated. This is partly due to the lack of an in vitro model that can facilitate $3 \mathrm{D}$ culture of HSCIW cells, recapturing their in vivo phenotype and thus, obtaining more physiologically relevant information. Research efforts targeting the engineering of the conventional outflow tract and its components are in their infancy. Applying nanotechnology for engineering the conventional outflow tract has great potential to mimic the nanoscale structure and outflow function of HSCIW cells. If successful, 3D culture of HSCIW cells will provide a valuable in vitro model that may revolutionize current thinking on the contribution of the SC to conventional outflow tract physiology and pathology and will hopefully translate into new drug modalities for glaucoma, targeting the SC.

\section{Author Contributions}

Cula N. Dautriche wrote and coordinated the overall preparation of this manuscript and tables. Yangzi Tian prepared all figures and index table. Overall editing, editorial direction and final editing of the manuscript were done by Yubing Xie and Susan T. Sharfstein. 


\title{
Conflicts of Interest
}

The authors declare no conflict of interest.

\author{
Abbreviations \\ Calcr1 Calcitonin Receptor 1 \\ CCBE1 Collagen and calcium-binding EGF domain-containing protein 1 \\ CCL21 Chemokine (C-C motif) ligand 21 \\ Clec2 C-type lectin-like receptor 2 \\ COUP-FTII Chicken ovalbumin upstream promoter-transcription factor 2 \\ CXADR Coxsackie virus and adenovirus receptor \\ Foxc2 Forkhead box protein $\mathrm{C} 2$ \\ GATA2 GATA binding protein 2 \\ Itga9 Integrin alpha-9 \\ LYVE-1 Lymphatic vessel endothelial hyaluronan receptor \\ Meis1 Meis homeobox 1 \\ Nfatc1 Nuclear factor of activated T-cells, cytoplasmic 1 \\ NRP2 Neuropilin 2 \\ PDPN Podoplanin \\ PECAM1 Platelet endothelial cell adhesion molecule \\ PROX1 Prospero homeobox protein 1 \\ RAC1 Ras-related C3 botulinum toxin substrate 1 \\ Ramp2 Receptor activity modifying protein 2 \\ Runx1 Runt-related transcription factor 1 \\ SLP76 Lymphocyte cytosolic protein 2 \\ Syk Spleen tyrosine kinase \\ TIE1 Tunica interna endothelial cell kinase 1 \\ TIE2 Tunica interna endothelial cell kinase 2 \\ VE-cadherin Vascular endothelial cadherin \\ VEFGR-2 Vascular endothelial growth factor 2 \\ VEFGR-3 Vascular endothelial growth factor 3 \\ vWF Von Willebrand factor
}

\section{References}

1. Mansouri, K.; Shaarawy, T. Update on Schlemm's canal based procedures. Middle East Afr. J. Ophthalmol. 2015, 22, 38-44.

2. Aspelund, A.; Tammela, T.; Antila, S.; Nurmi, H.; Leppanen, V.M.; Zarkada, G.; Stanczuk, L.; Francois, M.; Makinen, T.; Saharinen, P.; et al. The Schlemm's canal is a VEGF-C/ VEGFR-3-responsive lymphatic-like vessel. J. Clin. Investig. 2014, 124, 3975-3986.

3. Ashpole, N.E.; Overby, D.R.; Ethier, C.R.; Stamer, W.D. Shear stress-triggered nitric oxide release from Schlemm's canal cells. Investig. Ophthalmol. Vis. Sci. 2014, 55, 8067-8076. 
4. Lutjen-Drecoll, E.; Rohen, J.W. [Endothelial studies of the Schlemm's canal using silver-impregnation technic]. Albrecht Von Graefes Arch. Klin. Exp. Ophthalmol. 1970, 180, $249-266$.

5. Ethier, C.R. The inner wall of Schlemm's canal. Exp. Eye Res. 2002, 74, 161-172.

6. Karl, M.O.; Fleischhauer, J.C.; Stamer, W.D.; Peterson-Yantorno, K.; Mitchell, C.H.; Stone, R.A.; Civan, M.M. Differential P1-purinergic modulation of human Schlemm's canal inner-wall cells. Am. J. Physiol. Cell Physiol. 2005, 288, C784-C794.

7. Vranka, J.A.; Kelley, M.J.; Acott, T.S.; Keller, K.E. Extracellular matrix in the trabecular meshwork: Intraocular pressure regulation and dysregulation in glaucoma. Exp. Eye Res. 2015, 133, 112-125.

8. Acott, T.S.; Kelley, M.J. Extracellular matrix in the trabecular meshwork. Exp. Eye Res. 2008, 86, 543-561.

9. Maepea, O.; Bill, A. Pressures in the juxtacanalicular tissue and Schlemm's canal in monkeys. Exp. Eye Res. 1992, 54, 879-883.

10. Johnson, M. What controls aqueous humour outflow resistance? Exp. Eye Res. 2006, 82, 545-557.

11. Johnson, M.C.; Kamm, R.D. The role of Schlemm's canal in aqueous outflow from the human eye. Investig. Ophthalmol. Vis. Sci. 1983, 24, 320-325.

12. Pampaloni, F.; Reynaud, E.G.; Stelzer, E.H. The third dimension bridges the gap between cell culture and live tissue. Nat. Rev. Mol. Cell Biol. 2007, 8, 839-845.

13. Braakman, S.T.; Pedrigi, R.M.; Read, A.T.; Smith, J.A.E.; Stamer, W.D.; Ethier, C.R.; Overby, D.R. Biomechanical strain as a trigger for pore formation in Schlemm's canal endothelial cells. Exp. Eye Res. 2014, 127, 224-235.

14. Park, C.Y.; Zhou, E.H.; Tambe, D.; Chen, B.; Lavoie, T.; Dowell, M.; Simeonov, A.; Maloney, D.J.; Marinkovic, A.; Tschumperlin, D.J.; et al. High-throughput screening for modulators of cellular contractile force. Integr. Biol. 2015, doi:10.1039/C5IB00054H.

15. Gong, H.; Tripathi, R.C.; Tripathi, B.J. Morphology of the aqueous outflow pathway. Microsc. Res. Tech. 1996, 33, 336-367.

16. Tamm, E.R. The trabecular meshwork outflow pathways: Structural and functional aspects. Exp. Eye Res. 2009, 88, 648-655.

17. Hamanaka, T.; Bill, A.; Ichinohasama, R.; Ishida, T. Aspects of the development of Schlemm's canal. Exp. Eye Res. 1992, 55, 479-488.

18. Heimark, R.L.; Kaochar, S.; Stamer, W.D. Human Schlemm's canal cells express the endothelial adherens proteins, VE-cadherin and PECAM-1. Curr. Eye Res. 2002, 25, 299-308.

19. Hamanaka, T.; Bill, A. Platelet aggregation on the endothelium of Schlemm's canal. Exp. Eye Res. 1994, 59, 249-256.

20. Johnstone, M.A.; Grant, W.M. Pressure-dependent changes in structures of the aqueous outflow system of human and monkey eyes. Am. J. Ophthalmol. 1973, 75, 365-383.

21. Ethier, C.R.; Coloma, F.M.; Sit, A.J.; Johnson, M. Two pore types in the inner-wall endothelium of Schlemm's canal. Investig. Ophthalmol. Vis. Sci. 1998, 39, 2041-2048.

22. Goel, M.; Picciani, R.G.; Lee, R.K.; Bhattacharya, S.K. Aqueous humor dynamics: A review. Open Ophthalmol. J. 2010, 4, 52-59.

23. Braakman, S.T.; Read, A.T.; Chan, D.W.; Ethier, C.R.; Overby, D.R. Colocalization of outflow segmentation and pores along the inner wall of Schlemm's canal. Exp. Eye Res. 2015, 130, 87-96. 
24. Smelser, G.K.; Ozanics, V. The development of the trabecular meshwork in primate eyes. Am. J. Ophthalmol. 1971, 71, 366-385.

25. Foets, B.; van den Oord, J.; Engelmann, K.; Missotten, L. A comparative immunohistochemical study of human corneotrabecular tissue. Graefes Arch. Clin. Exp. Ophthalmol. 1992, 230, 269-274.

26. Wulle, K.G. Electron microscopic observations of the development of Schlemm's canal in the human eye. Trans. Am. Acad. Ophthalmol. Otolaryngol. 1968, 72, 765-773.

27. Ramirez, J.M.; Ramirez, A.I.; Salazar, J.J.; Rojas, B.; de Hoz, R.; Trivino, A. Schlemm's canal and the collector channels at different developmental stages in the human eye. Cells Tissues Organs 2004, 178, 180-185.

28. Park, D.Y.; Lee, J.; Park, I.; Choi, D.; Lee, S.; Song, S.; Hwang, Y.; Hong, K.Y.; Nakaoka, Y.; Makinen, T.; et al. Lymphatic regulator PROX1 determines Schlemm's canal integrity and identity. J. Clin. Investig. 2014, 124, 3960-3974.

29. Yang, Y.; Oliver, G. Development of the mammalian lymphatic vasculature. J. Clin. Investig. 2014, 124, 888-897.

30. Oliver, G.; Srinivasan, R.S. Endothelial cell plasticity: How to become and remain a lymphatic endothelial cell. Development 2010, 137, 363-372.

31. Hagerling, R.; Pollmann, C.; Andreas, M.; Schmidt, C.; Nurmi, H.; Adams, R.H.; Alitalo, K.; Andresen, V.; Schulte-Merker, S.; Kiefer, F. A novel multistep mechanism for initial lymphangiogenesis in mouse embryos based on ultramicroscopy. EMBO J. 2013, 32, 629-644.

32. Hong, Y.K.; Detmar, M. PROX1, master regulator of the lymphatic vasculature phenotype. Cell Tissue Res. 2003, 314, 85-92.

33. Francois, M.; Caprini, A.; Hosking, B.; Orsenigo, F.; Wilhelm, D.; Browne, C.; Paavonen, K.; Karnezis, T.; Shayan, R.; Downes, M.; et al. Sox18 induces development of the lymphatic vasculature in mice. Nature 2008, 456, 643-647.

34. Yamazaki, T.; Yoshimatsu, Y.; Morishita, Y.; Miyazono, K.; Watabe, T. Coup-TFII regulates the functions of PROX1 in lymphatic endothelial cells through direct interaction. Genes Cells 2009, 14, 425-434.

35. Yang, Y.; García-Verdugo, J.M.; Soriano-Navarro, M.; Srinivasan, R.S.; Scallan, J.P.; Singh, M.K.; Epstein, J.A.; Oliver, G. Lymphatic endothelial progenitors bud from the cardinal vein and intersomitic vessels in mammalian embryos. Blood 2012, 120, 2340-2348.

36. Breiteneder-Geleff, S.; Soleiman, A.; Kowalski, H.; Horvat, R.; Amann, G.; Kriehuber, E.; Diem, K.; Weninger, W.; Tschachler, E.; Alitalo, K.; et al. Angiosarcomas express mixed endothelial phenotypes of blood and lymphatic capillaries: Podoplanin as a specific marker for lymphatic endothelium. Am. J. Pathol. 1999, 154, 385-394.

37. Kaipainen, A.; Korhonen, J.; Mustonen, T.; van Hinsbergh, V.W.; Fang, G.H.; Dumont, D.; Breitman, M.; Alitalo, K. Expression of the FMS-like tyrosine kinase 4 gene becomes restricted to lymphatic endothelium during development. Proc. Natl. Acad. Sci. USA 1995, 92, 3566-3570.

38. Le Guen, L.; Karpanen, T.; Schulte, D.; Harris, N.C.; Koltowska, K.; Roukens, G.; Bower, N.I.; van Impel, A.; Stacker, S.A.; Achen, M.G.; et al. CCBE1 regulates VEGFC-mediated induction of VEGFR3 signaling during embryonic lymphangiogenesis. Development 2014, 141, 1239-1249. 
39. Lin, F.J.; Chen, X.; Qin, J.; Hong, Y.K.; Tsai, M.J.; Tsai, S.Y. Direct transcriptional regulation of neuropilin-2 by COUP-TFII modulates multiple steps in murine lymphatic vessel development. J. Clin. Investig. 2010, 120, 1694-1707.

40. D’Amico, G.; Jones, D.T.; Nye, E.; Sapienza, K.; Ramjuan, A.R.; Reynolds, L.E.; Robinson, S.D.; Kostourou, V.; Martinez, D.; Aubyn, D.; et al. Regulation of lymphatic-blood vessel separation by endothelial RAC1. Development 2009, 136, 4043-4053.

41. Banerji, S.; Ni, J.; Wang, S.-X.; Clasper, S.; Su, J.; Tammi, R.; Jones, M.; Jackson, D.G. LYVE-1, a new homologue of the CD44 glycoprotein, is a lymph-specific receptor for hyaluronan. J. Cell Biol. 1999, 144, 789-801.

42. Kulkarni, R.M.; Greenberg, J.M.; Akeson, A.L. NFATC1 regulates lymphatic endothelial development. Mech. Dev. 2009, 126, 350-365.

43. Lim, K.-C.; Hosoya, T.; Brandt, W.; Ku, C.-J.; Hosoya-Ohmura, S.; Camper, S.A.; Yamamoto, M.; Engel, J.D. Conditional GATA2 inactivation results in HSC loss and lymphatic mispatterning. J. Clin. Investig. 2012, 122, 3705-3717.

44. Kazenwadel, J.; Secker, G.A.; Liu, Y.J.; Rosenfeld, J.A.; Wildin, R.S.; Cuellar-Rodriguez, J.; Hsu, A.P.; Dyack, S.; Fernandez, C.V.; Chong, C.-E.; et al. Loss-of-function germline GATA2 mutations in patients with MDS/AML or monomac syndrome and primary lymphedema reveal a key role for GATA2 in the lymphatic vasculature. Blood 2012, 119, 1283-1291.

45. Fritz-Six, K.L.; Dunworth, W.P.; Li, M.; Caron, K.M. Adrenomedullin signaling is necessary for murine lymphatic vascular development. J. Clin. Investig. 2008, 118, 40-50.

46. Qu, X.; Tompkins, K.; Batts, L.E.; Puri, M.; Baldwin, S. Abnormal embryonic lymphatic vessel development in TIE1 hypomorphic mice. Development 2010, 137, 1285-1295.

47. Abtahian, F.; Guerriero, A.; Sebzda, E.; Lu, M.M.; Zhou, R.; Mocsai, A.; Myers, E.E.; Huang, B.; Jackson, D.G.; Ferrari, V.A.; et al. Regulation of blood and lymphatic vascular separation by signaling proteins SLP-76 and SYK. Science 2003, 299, 247-251.

48. Srinivasan, R.S.; Dillard, M.E.; Lagutin, O.V.; Lin, F.-J.; Tsai, S.; Tsai, M.-J.; Samokhvalov, I.M.; Oliver, G. Lineage tracing demonstrates the venous origin of the mammalian lymphatic vasculature. Genes Dev. 2007, 21, 2422-2432.

49. Carramolino, L.; Fuentes, J.; Garcia-Andres, C.; Azcoitia, V.; Riethmacher, D.; Torres, M. Platelets play an essential role in separating the blood and lymphatic vasculatures during embryonic angiogenesis. Circ. Res. 2010, 106, 1197-1201.

50. Uhrin, P.; Zaujec, J.; Breuss, J.M.; Olcaydu, D.; Chrenek, P.; Stockinger, H.; Fuertbauer, E.; Moser, M.; Haiko, P.; Fassler, R.; et al. Novel function for blood platelets and podoplanin in developmental separation of blood and lymphatic circulation. Blood 2010, 115, 3997-4005.

51. Suzuki-Inoue, K.; Inoue, O.; Ding, G.; Nishimura, S.; Hokamura, K.; Eto, K.; Kashiwagi, H.; Tomiyama, Y.; Yatomi, Y.; Umemura, K.; et al. Essential in vivo roles of the c-type lectin receptor clec-2: Embryonic/neonatal lethality of CLEC-2-deficient mice by blood/lymphatic misconnections and impaired thrombus formation of CLEC-2-deficient platelets. J. Biol. Chem. 2010, 285, 24494-24507.

52. Mirza, M.; Pang, M.-F.; Zaini, M.A.; Haiko, P.; Tammela, T.; Alitalo, K.; Philipson, L.; Fuxe, J.; Sollerbrant, K. Essential role of the coxsacki- and adenovirus receptor (CAR) in development of the lymphatic system in mice. PLoS ONE 2012, 7, doi:10.1371/journal.pone.0037523. 
53. Kizhatil, K.; Ryan, M.; Marchant, J.K.; Henrich, S.; John, S.W.M. Schlemm's canal is a unique vessel with a combination of blood vascular and lymphatic phenotypes that forms by a novel developmental process. PLoS Biol. 2014, 12, doi:10.1371/journal.pbio.1001912.

54. Truong, T.N.; Li, H.; Hong, Y.-K.; Chen, L. Novel characterization and live imaging of Schlemm's canal expressing PROX-1. PLoS ONE 2014, 9, doi:10.1371/journal.pone.0098245.

55. Karpinich, N.O.; Caron, K.M. Schlemm's canal: More than meets the eye, lymphatics in disguise. J. Clin. Investig. 2014, 124, 3701-3703.

56. Grant, W.M. Further studies on facility of flow through the trabecular meshwork. AMA Arch. Ophthalmol. 1958, 60, 523-533.

57. Ramos, R.F.; Hoying, J.B.; Witte, M.H.; Daniel Stamer, W. Schlemm's canal endothelia, lymphatic, or blood vasculature? J. Glaucoma 2007, 16, 391-405.

58. Allingham, R.R.; de Kater, A.W.; Ethier, C.R. Schlemm's canal and primary open angle glaucoma: Correlation between Schlemm's canal dimensions and outflow facility. Exp. Eye Res. 1996, 62, 101-109.

59. Kagemann, L.; Wang, B.; Wollstein, G.; Ishikawa, H.; Nevins, J.E.; Nadler, Z.; Sigal, I.A.; Bilonick, R.A.; Schuman, J.S. IOP elevation reduces Schlemm's canal cross-sectional area. Investig. Ophthalmol. Vis. Sci. 2014, 55, 1805-1809.

60. Kagemann, L.; Wollstein, G.; Ishikawa, H.; Bilonick, R.A.; Brennen, P.M.; Folio, L.S.; Gabriele, M.L.; Schuman, J.S. Identification and assessment of Schlemm's canal by spectral-domain optical coherence tomography. Investig. Ophthalmol. Vis. Sci. 2010, 51, 4054-4059.

61. Kagemann, L.; Nevins, J.E.; Jan, N.-J.; Wollstein, G.; Ishikawa, H.; Kagemann, J.; Sigal, I.A.; Nadler, Z.; Ling, Y.; Schuman, J.S. Characterisation of Schlemm's canal cross-sectional area. Br. J. Ophthalmol. 2014, 98, ii10-ii14.

62. Kagemann, L.; Wollstein, G.; Ishikawa, H.; Sigal, I.A.; Folio, L.S.; Xu, J.; Gong, H.; Schuman, J.S. 3D visualization of aqueous humor outflow structures in-situ in humans. Exp. Eye Res. 2011, 93, 308-315.

63. Kagemann, L.; Wollstein, G.; Ishikawa, H.; Nadler, Z.; Sigal, I.A.; Folio, L.S.; Schuman, J.S. Visualization of the conventional outflow pathway in the living human eye. Ophthalmology 2012, 119, 1563-1568.

64. Dvorak-Theobald, G. Schlemm's canal: Its anastomoses and anatomic relations. Trans. Am. Ophthalmol. Soc. 1934, 32, 574-595.

65. Rosenquist, R.; Epstein, D.; Melamed, S.; Johnson, M.; Grant, W.M. Outflow resistance of enucleated human eyes at two different perfusion pressures and different extents of trabeculotomy. Curr. Eye Res. 1989, 8, 1233-1240.

66. Grierson, I.; Lee, W.R.; Abraham, S.; Howes, R.C. Associations between the cells of the walls of Schlemm's canal. Albrecht Von Graefes Arch. Klin. Exp. Ophthalmol. 1978, 208, 33-47.

67. Hamanaka, T.; Thornell, L.E.; Bill, A. Cytoskeleton and tissue origin in the anterior cynomolgus monkey eye. Jpn. J. Ophthalmol. 1997, 41, 138-149.

68. Ethier, C.R.; Read, A.T.; Chan, D. Biomechanics of Schlemm's canal endothelial cells: Influence on f-actin architecture. Biophys. J. 2004, 87, 2828-2837.

69. Grierson, I.; Lee, W.R. Pressure-induced changes in the ultrastructure of the endothelium lining Schlemm's canal. Am. J. Ophthalmol. 1975, 80, 863-884. 
70. Bill, A.; Svedbergh, B. Scanning electron microscopic studies of the trabecular meshwork and the canal of Schlemm-An attempt to localize the main resistance to outflow of aqueous humor in man. Acta Ophthalmol. 1972, 50, 295-320.

71. Tripathi, R.C. Ultrastructure of Schlemm's canal in relation to aqueous outflow. Exp. Eye Res. 1968, 7, 335-341.

72. Holmberg, A. The fine structure of the inner wall of Schlemms canal. Arch. Ophthalmol. 1959, 62, 956-958.

73. Epstein, D.L.; Rohen, J.W. Morphology of the trabecular meshwork and inner-wall endothelium after cationized ferritin perfusion in the monkey eye. Investig. Ophthalmol. Vis. Sci. 1991, 32, $160-171$.

74. Herrnberger, L.; Ebner, K.; Junglas, B.; Tamm, E.R. The role of plasmalemma vesicle-associated protein (PLVAP) in endothelial cells of Schlemm's canal and ocular capillaries. Exp. Eye Res. 2012, 105, 27-33.

75. Inomata, H.; Bill, A.; Smelser, G.K. Aqueous humor pathways through the trabecular meshwork and into Schlemm's canal in the cynomolgus monkey (Macaca Irus). An electron microscopic study. Am. J. Ophthalmol. 1972, 73, 760-789.

76. Overby, D.R.; Stamer, W.D.; Johnson, M. The changing paradigm of outflow resistance generation: Towards synergistic models of the JCT and inner wall endothelium. Exp. Eye Res. 2009, 88, 656-670.

77. Chang, J.Y.; Folz, S.J.; Laryea, S.N.; Overby, D.R. Multi-scale analysis of segmental outflow patterns in human trabecular meshwork with changing intraocular pressure. J. Ocul. Pharmacol. Ther. 2014, 30, 213-223.

78. Hann, C.R.; Fautsch, M.P. Preferential fluid flow in the human trabecular meshwork near collector channels. Investig. Ophthalmol. Vis. Sci. 2009, 50, 1692-1697.

79. Stamer, W.D.; Roberts, B.C.; Howell, D.N.; Epstein, D.L. Isolation, culture, and characterization of endothelial cells from Schlemm's canal. Investig. Ophthalmol. Vis. Sci. 1998, 39, 1804-1812.

80. Perkumas, K.M.; Stamer, W.D. Protein markers and differentiation in culture for Schlemm's canal endothelial cells. Exp. Eye Res. 2012, 96, 82-87.

81. Tian, B.; Geiger, B.; Epstein, D.L.; Kaufman, P.L. Cytoskeletal involvement in the regulation of aqueous humor outflow. Investig. Ophthalmol. Vis. Sci. 2000, 41, 619-623.

82. Hristov, M.; Weber, C. Endothelial progenitor cells: Characterization, pathophysiology, and possible clinical relevance. J. Cell Mol. Med. 2004, 8, 498-508.

83. Welti, J.; Loges, S.; Dimmeler, S.; Carmeliet, P. Recent molecular discoveries in angiogenesis and antiangiogenic therapies in cancer. J. Clin. Investig. 2013, 123, 3190-3200.

84. Garlanda, C.; Dejana, E. Heterogeneity of endothelial cells. Specific markers. Arterioscler. Thromb. Vasc. Biol. 1997, 17, 1193-1202.

85. Gavard, J. Endothelial permeability and VE-cadherin: A wacky comradeship. Cell Adh. Migr. 2014, 8, 158-164.

86. Lenting, P.J.; Christophe, O.D.; Denis, C.V. von Willebrand factor biosynthesis, secretion, and clearance: connecting the far ends. Blood 2015, 125, 2019-2028.

87. Ikomi, F.; Kawai, Y.; Ohhashi, T. Recent advance in lymph dynamic analysis in lymphatics and lymph nodes. Ann. Vasc. Dis. 2012, 5, 258-268. 
88. Stamer, W.D.; Braakman, S.T.; Zhou, E.H.; Ethier, C.R.; Fredberg, J.J.; Overby, D.R.; Johnson, M. Biomechanics of Schlemm's canal endothelium and intraocular pressure reduction. Prog. Retin. Eye Res. 2015, 44, 86-98.

89. Miteva, D.O.; Rutkowski, J.M.; Dixon, J.B.; Kilarski, W.; Shields, J.D.; Swartz, M.A. Transmural flow modulates cell and fluid transport functions of lymphatic endothelium. Circ. Res. 2010, 106, 920-931.

90. Dautriche, C.N.; Szymanski, D.; Kerr, M.; Torrejon, K.Y.; Bergkvist, M.; Xie, Y.; Danias, J.; Stamer, W.D.; Sharfstein, S.T. A biomimetic Schlemm's canal inner wall: A model to study outflow physiology, glaucoma pathology and high-throughput drug screening. Biomaterials 2015, 65, 86-92.

91. Raviola, G.; Raviola, E. Paracellular route of aqueous outflow in the trabecular meshwork and canal of Schlemm. A freeze-fracture study of the endothelial junctions in the sclerocorneal angle of the macaque monkey eye. Investig. Ophthalmol. Vis. Sci. 1981, 21, 52-72.

92. Swartz, M.A. The physiology of the lymphatic system. Adv. Drug Deliv. Rev. 2001, 50, 3-20.

93. Overby, D.R.; Zhou, E.H.; Vargas-Pinto, R.; Pedrigi, R.M.; Fuchshofer, R.; Braakman, S.T.; Gupta, R.; Perkumas, K.M.; Sherwood, J.M.; Vahabikashi, A.; et al. Altered mechanobiology of Schlemm's canal endothelial cells in glaucoma. Proc. Natl. Acad. Sci. USA 2014, 111, 13876-13881.

94. Vargas-Pinto, R.; Lai, J.; Gong, H.; Ethier, C.R.; Johnson, M. Finite element analysis of the pressure-induced deformation of Schlemm's canal endothelial cells. Biomech. Model. Mechanobiol. 2014, 14, 851-863.

95. Zhou, E.H.; Krishnan, R.; Stamer, W.D.; Perkumas, K.M.; Rajendran, K.; Nabhan, J.F.; Lu, Q.; Fredberg, J.J.; Johnson, M. Mechanical responsiveness of the endothelial cell of Schlemm's canal: Scope, variability and its potential role in controlling aqueous humour outflow. J. R. Soc. Interf. 2012, 9, 1144-1155.

96. Zeng, D.; Juzkiw, T.; Read, A.T.; Chan, D.W.H.; Glucksberg, M.R.; Ethier, C.R.; Johnson, M. Young's modulus of elasticity of Schlemm's canal endothelial cells. Biomech. Model. Mechanobiol. 2010, 9, 19-33.

97. Johnson, M.; Shapiro, A.; Ethier, C.R.; Kamm, R.D. Modulation of outflow resistance by the pores of the inner wall endothelium. Investig. Ophthalmol. Vis. Sci. 1992, 33, 1670-1675.

98. Johnson, M.; Johnson, D.H.; Kamm, R.D.; DeKater, A.W.; Epstein, D.L. The filtration characteristics of the aqueous outflow system. Exp. Eye Res. 1990, 50, 407-418.

99. Allingham, R.R.; de Kater, A.W.; Ethier, C.R.; Anderson, P.J.; Hertzmark, E.; Epstein, D.L. The relationship between pore density and outflow facility in human eyes. Investig. Ophthalmol. Vis. Sci. 1992, 33, 1661-1669.

100. Alvarado, J.A.; Yeh, R.-F.; Franse-Carman, L.; Marcellino, G.; Brownstein, M.J. Interactions between endothelia of the trabecular meshwork and of Schlemm's canal: A new insight into the regulation of aqueous outflow in the eye. Trans. Am. Ophthalmol. Soc. 2005, 103, 148-163.

101. Curcio, C.A. Declining availability of human eye tissues for research. Investig. Ophthalmol. Vis. Sci. 2006, 47, 2747-2749.

102. Lei, Y.; Overby, D.R.; Read, A.T.; Stamer, W.D.; Ethier, C.R. A new method for selection of angular aqueous plexus cells from porcine eyes: A model for Schlemm's canal endothelium. Investig. Ophthalmol. Vis. Sci. 2010, 51, 5744-5750. 
103. Ellis, D.Z.; Sharif, N.A.; Dismuke, W.M. Endogenous regulation of human Schlemm's canal cell volume by nitric oxide signaling. Investig. Ophthalmol. Vis. Sci. 2010, 51, 5817-5824.

104. Nishikawa, S.-I.; Goldstein, R.A.; Nierras, C.R. The promise of human induced pluripotent stem cells for research and therapy. Nat. Rev. Mol. Cell Biol. 2008, 9, 725-729.

105. Jones, D.L.; Wagers, A.J. No place like home: Anatomy and function of the stem cell niche. Nat. Rev. Mol. Cell Biol. 2008, 9, 11-21.

106. MacArthur, B.D.; Ma'ayan, A.; Lemischka, I.R. Systems biology of stem cell fate and cellular reprogramming. Nat. Rev. Mol. Cell Biol. 2009, 10, 672-681.

107. Tay, C.Y.; Sathiyanathan, P.; Chu, S.W.; Stanton, L.W.; Wong, T.T. Identification and characterization of mesenchymal stem cells derived from the trabecular meshwork of the human eye. Stem Cells Dev. 2012, 21, 1381-1390.

108. Du, Y.; Roh, D.S.; Mann, M.M.; Funderburgh, M.L.; Funderburgh, J.L.; Schuman, J.S. Multipotent stem cells from trabecular meshwork become phagocytic tm cells. Investig. Ophthalmol. Vis. Sci. 2012, 53, 1566-1575.

109. Ding, Q.J.; Zhu, W.; Cook, A.C.; Anfinson, K.R.; Tucker, B.A.; Kuehn, M.H. Induction of trabecular meshwork cells from induced pluripotent stem cells. Investig. Ophthalmol. Vis. Sci. 2014, 55, 7065-7072.

110. Du, Y.; Yun, H.; Yang, E.; Schuman, J.S. Stem cells from trabecular meshwork home to TM tissue in vivo. Investig. Ophthalmol. Vis. Sci. 2013, 54, 1450-1459.

111. Carmeliet, P. Angiogenesis in life, disease and medicine. Nature 2005, 438, 932-936.

112. Kume, T. Specification of arterial, venous, and lymphatic endothelial cells during embryonic development. Histol. Histopathol. 2010, 25, 637-646.

113. Swift, M.R.; Weinstein, B.M. Arterial-venous specification during development. Circ. Res. 2009, 104, 576-588.

114. You, L.R.; Lin, F.J.; Lee, C.T.; DeMayo, F.J.; Tsai, M.J.; Tsai, S.Y. Suppression of notch signalling by the COUP-TFII transcription factor regulates vein identity. Nature 2005, 435, 98-104.

115. Keller, K.E.; Acott, T.S. The juxtacanalicular region of ocular trabecular meshwork: A tissue with a unique extracellular matrix and specialized function. J. Ocul. Biol. 2013, 1, 10:1-10:7.

116. Adachi, T.; Osako, Y.; Tanaka, M.; Hojo, M.; Hollister, S.J. Framework for optimal design of porous scaffold microstructure by computational simulation of bone regeneration. Biomaterials 2006, 27, 3964-3972.

117. Hollister, S.J. Porous scaffold design for tissue engineering. Nat. Mater. 2005, 4, 518-524.

118. Hutmacher, D.W.; Sittinger, M.; Risbud, M.V. Scaffold-based tissue engineering: Rationale for computer-aided design and solid free-form fabrication systems. Trends Biotechnol. 2004, 22, 354-362.

119. Ravi, S.; Chaikof, E.L. Biomaterials for vascular tissue engineering. Regen. Med. 2010, 5, 107-120.

120. Ravi, S.; Qu, Z.; Chaikof, E.L. Polymeric materials for tissue engineering of arterial substitutes. Vascular 2009, 17, S45-S54.

121. Hasan, A.; Memic, A.; Annabi, N.; Hossain, M.; Paul, A.; Dokmeci, M.R.; Dehghani, F.; Khademhosseini, A. Electrospun scaffolds for tissue engineering of vascular grafts. Acta Biomater.

2014, 10, 11-25. 
122. Woods, I.; Flanagan, T.C. Electrospinning of biomimetic scaffolds for tissue-engineered vascular grafts: Threading the path. Expert Rev. Cardiovasc. Ther. 2014, 12, 815-832.

123. Cheung, H.-Y.; Lau, K.-T.; Lu, T.-P.; Hui, D. A critical review on polymer-based bio-engineered materials for scaffold development. Compos. B Eng. 2007, 38, 291-300.

124. Rhee, D.J.; Haddadin, R.I.; Kang, M.H.; Oh, D.J. Matricellular proteins in the trabecular meshwork. Exp. Eye Res. 2009, 88, 694-703.

125. Genasetti, A.; Vigetti, D.; Viola, M.; Karousou, E.; Moretto, P.; Rizzi, M.; Bartolini, B.; Clerici, M.; Pallotti, F.; De Luca, G.; et al. Hyaluronan and human endothelial cell behavior. Connect. Tissue Res. 2008, 49, 120-123.

126. Turner, N.J.; Kielty, C.M.; Walker, M.G.; Canfield, A.E. A novel hyaluronan-based biomaterial (Hyaff- $11^{\circledR}$ ) as a scaffold for endothelial cells in tissue engineered vascular grafts. Biomaterials 2004, 25, 5955-5964.

127. Ibrahim, S.; Ramamurthi, A. Hyaluronic acid cues for functional endothelialization of vascular constructs. J. Tissue Eng. Regen. Med. 2008, 2, 22-32.

128. Boccafoschi, F.; Habermehl, J.; Vesentini, S.; Mantovani, D. Biological performances of collagen-based scaffolds for vascular tissue engineering. Biomaterials 2005, 26, 7410-7417.

129. Boland, E.D.; Matthews, J.A.; Pawlowski, K.J.; Simpson, D.G.; Wnek, G.E.; Bowlin, G.L. Electrospinning collagen and elastin: Preliminary vascular tissue engineering. Front. Biosci. 2004, 9, 1422-1432.

130. Berglund, J.D.; Nerem, R.M.; Sambanis, A. Incorporation of intact elastin scaffolds in tissue-engineered collagen-based vascular grafts. Tissue Eng. 2004, 10, 1526-1535.

131. Jopling, C.; Boue, S.; Izpisua Belmonte, J.C. Dedifferentiation, transdifferentiation and reprogramming: Three routes to regeneration. Nat. Rev. Mol. Cell Biol. 2011, 12, 79-89.

132. Hannum, C.; Culpepper, J.; Campbell, D.; McClanahan, T.; Zurawski, S.; Bazan, J.F.; Kastelein, R.; Hudak, S.; Wagner, J.; Mattson, J.; et al. Ligand for FLT3/FLK2 receptor tyrosine kinase regulates growth of haematopoietic stem cells and is encoded by variant rnas. Nature 1994, 368, 643-648.

133. Meng, X.; Leslie, P.; Zhang, Y.; Dong, J. Stem cells in a three-dimensional scaffold environment. Springer Plus 2014, 3, doi:10.1186/2193-1801-3-80.

134. Taylor-Weiner, H.; Schwarzbauer, J.E.; Engler, A.J. Defined extracellular matrix components are necessary for definitive endoderm induction. Stem Cells 2013, 31, 2084-2094.

135. McBeath, R.; Pirone, D.M.; Nelson, C.M.; Bhadriraju, K.; Chen, C.S. Cell shape, cytoskeletal tension, and RhoA regulate stem cell lineage commitment. Dev. Cell 2004, 6, 483-495.

136. Liersch, R.; Nay, F.; Lu, L.; Detmar, M. Induction of lymphatic endothelial cell differentiation in embryoid bodies. Blood 2006, 107, 1214-1216.

137. Alexander, J.P.; Acott, T.S. Involvement of the ERK-MAP kinase pathway in TNFalpha regulation of trabecular matrix metalloproteinases and TIMPS. Investig. Ophthalmol. Vis. Sci. 2003, 44, 164-169.

138. Bradley, J.M.; Anderssohn, A.M.; Colvis, C.M.; Parshley, D.E.; Zhu, X.H.; Ruddat, M.S.; Samples, J.R.; Acott, T.S. Mediation of laser trabeculoplasty-induced matrix metalloproteinase expression by IL-1beta and TNFalpha. Investig. Ophthalmol. Vis. Sci. 2000, 41, 422-430. 
139. Chang, J.Y.; Stamer, W.D.; Bertrand, J.; Read, A.T.; Marando, C.M.; Ethier, C.R.; Overby, D.R. The role of nitric oxide in murine conventional outflow physiology. Am. J. Physiol. Cell Physiol. 2015, 309, C205-C214.

140. Huang, N.F.; Fleissner, F.; Sun, J.; Cooke, J.P. Role of nitric oxide signaling in endothelial differentiation of embryonic stem cells. Stem Cells Dev. 2010, 19, 1617-1625.

141. Bishop, C.; Kim, J.; Green, J. Biomolecule delivery to engineer the cellular microenvironment for regenerative medicine. Ann. Biomed. Eng. 2014, 42, 1557-1572.

142. Quake, S.R.; Scherer, A. From micro- to nanofabrication with soft materials. Science 2000, 290, 1536-1540.

143. Baker, B.M.; Chen, C.S. Deconstructing the third dimension: How 3D culture microenvironments alter cellular cues. J. Cell Sci. 2012, 125, 3015-3024.

144. Lee, S.-H.; Shin, H. Matrices and scaffolds for delivery of bioactive molecules in bone and cartilage tissue engineering. Adv. Drug Deliv. Rev. 2007, 59, 339-359.

145. Chung, H.J.; Park, T.G. Surface engineered and drug releasing pre-fabricated scaffolds for tissue engineering. Adv. Drug Deliv. Rev. 2007, 59, 249-262.

146. Pedrigi, R.M.; Simon, D.; Reed, A.; Stamer, W.D.; Overby, D.R. A model of giant vacuole dynamics in human Schlemm's canal endothelial cells. Exp. Eye Res. 2011, 92, 57-66.

147. Burke, A.G.; Zhou, W.; O’Brien, E.T.; Roberts, B.C.; Stamer, W.D. Effect of hydrostatic pressure gradients and $\mathrm{Na}_{2}$ EDTA on permeability of human Schlemm's canal cell monolayers. Curr. Eye Res. 2004, 28, 391-398.

148. Stamer, W.D.; Roberts, B.C.; Epstein, D.L. Hydraulic pressure stimulates adenosine 3',5'-cyclic monophosphate accumulation in endothelial cells from Schlemm's canal. Investig. Ophthalmol. Vis. Sci. 1999, 40, 1983-1988.

149. Schindler, M.; Nur, E.K.A.; Ahmed, I.; Kamal, J.; Liu, H.Y.; Amor, N.; Ponery, A.S.; Crockett, D.P.; Grafe, T.H.; Chung, H.Y.; et al. Living in three dimensions: 3D nanostructured environments for cell culture and regenerative medicine. Cell Biochem. Biophys. 2006, 45, 215-227.

150. Albelda, S.M.; Sampson, P.M.; Haselton, F.R.; McNiff, J.M.; Mueller, S.N.; Williams, S.K.; Fishman, A.P.; Levine, E.M. Permeability characteristics of cultured endothelial cell monolayers. J. Appl. Physiol. 1988, 64, 308-322.

151. Santaguida, S.; Janigro, D.; Hossain, M.; Oby, E.; Rapp, E.; Cucullo, L. Side by side comparison between dynamic versus static models of blood-brain barrier in vitro: A permeability study. Brain Res. 2006, 1109, 1-13.

152. Torrejon, K.Y.; Pu, D.; Bergkvist, M.; Danias, J.; Sharfstein, S.T.; Xie, Y. Recreating a human trabecular meshwork outflow system on microfabricated porous structures. Biotechnol. Bioeng. 2013, 110, 3205-3218.

153. Dautriche, C.N.; Xie, Y.; Sharfstein, S.T. Walking through trabecular meshwork biology: Toward engineering design of outflow physiology. Biotechnol. Adv. 2014, 32, 971-983.

154. Helm, C.L.; Zisch, A.; Swartz, M.A. Engineered blood and lymphatic capillaries in 3-D VEGF-fibrin-collagen matrices with interstitial flow. Biotechnol. Bioeng. 2007, 96, 167-176.

155. Ng, C.P.; Helm, C.L.; Swartz, M.A. Interstitial flow differentially stimulates blood and lymphatic endothelial cell morphogenesis in vitro. Microvasc. Res. 2004, 68, 258-264. 
156. Boardman, K.C.; Swartz, M.A. Interstitial flow as a guide for lymphangiogenesis. Circ. Res. 2003, 92, 801-808.

157. Niebruegge, S.; Bauwens, C.L.; Peerani, R.; Thavandiran, N.; Masse, S.; Sevaptisidis, E.; Nanthakumar, K.; Woodhouse, K.; Husain, M.; Kumacheva, E.; et al. Generation of human embryonic stem cell-derived mesoderm and cardiac cells using size-specified aggregates in an oxygen-controlled bioreactor. Biotechnol. Bioeng. 2009, 102, 493-507.

158. Sargent, C.Y.; Berguig, G.Y.; McDevitt, T.C. Cardiomyogenic differentiation of embryoid bodies is promoted by rotary orbital suspension culture. Tissue Eng. A 2009, 15, 331-342.

159. Jing, D.; Parikh, A.; Tzanakakis, E.S. Cardiac cell generation from encapsulated embryonic stem cells in static and scalable culture systems. Cell Transplant. 2010, 19, 1397-1412.

160. Illi, B.; Scopece, A.; Nanni, S.; Farsetti, A.; Morgante, L.; Biglioli, P.; Capogrossi, M.C.; Gaetano, C. Epigenetic histone modification and cardiovascular lineage programming in mouse embryonic stem cells exposed to laminar shear stress. Circ. Res. 2005, 96, 501-508.

161. Hazeltine, L.B.; Selekman, J.A.; Palecek, S.P. Engineering the human pluripotent stem cell microenvironment to direct cell fate. Biotechnol. Adv. 2013, 31, 1002-1091.

(C) 2015 by the authors; licensee MDPI, Basel, Switzerland. This article is an open access article distributed under the terms and conditions of the Creative Commons Attribution license (http://creativecommons.org/licenses/by/4.0/). 